\title{
RUDRA-SIVA AS DEPICTED IN THE UPANISADIC LITERATURE
}

\author{
Dr. Maumita Bhattacharjee \\ Gauhati University, Assam, India \\ Dr. Jyotsna Devi \\ Gauhati University, Assam, India
}

\begin{abstract}
The Vedas are regarded as the most sacred and ancient texts of Hinduism. The word Veda comes from the root 'vid' to know, with the suffix 'ac' or 'ghan'. There are four Vedas in number The Rgveda, the Yajurveda, The Atharvaveda and the Samaveda. Each Veda has been classified into four sub-divisions the Samhitas, the Brahmanas, the Aranyakas and the Upanisads. The concept of Rudra-Siva gradually developed and he occupies a higher platform in the Upanisadic period. Rudra-Siva is treated as Brahman in the Upanisads. He is regarded as Girisanta, Giritra, Bhagavan, Paramatma, Brahma, Visnu, Mahesvara etc. Rudra manifests himself into three forms, i.e. Brahma, Visnu and Mahesvara according to the need of the universe.

This paper is an effort to present the characteristic features of Rudra-Siva as reflected in the Upanisads.
\end{abstract}

Key words: Rudra, Upanisad, Brahman, Atman, Paramatma

Cite this Article: Maumita Bhattacharjee and Jyotsna Devi, Rudra-Siva as Depicted in the Upanisadic Literature, International Journal of Management, 11(12), 2020, pp 2158-2162.

http://iaeme.com/Home/issue/IJM?Volume=11\&Issue $=12$

\section{INTRODUCTION}

The concept of Rudra-Siva gradually developed and he occupies a higher platform in the Upanisadic period. Rudra-Siva is treated as Brahman in the Upanisads. He is regarded as Girisanta, Giritra, Bhagavan, Paramatma, Brahma, Visnu, Mahesvara etc. Rudra manifests himself into three forms, i.e. Brahma, Visnu and Mahesvara according to the need of the universe

\section{METHODOLOGY}

In this paper, mainly analytical method is used. Descriptive method is also adopted in some places. 


\section{DISCUSION}

In the Upanisadic literature, a new trend has been emerged. Here, all the individual gods are said to be subordinate of the Brahman who is the Ultimate Reality according to the Upanisads. Through the Upanisadic literature the unity between Brahman and Atman or the identity of the human soul and Ultimate Reality can be known. ${ }^{1}$

The Vedic Indians chanted the Vedic hymns which are described in the Samhitas to eulogize some Supreme Beings. The devotees propitiated the gods by performing the rituals for obtaining their mercy. The quest of the worshippers had developed the concept of a superhuman nature behind it. The Aryans believed in a responsive agent called god behind all these phenomena seeing the phenomena of nature like clouds' gathering, rising and setting of the sun, lightning etc.

The Vedic Indians accepted the gods and in later period, these gods are regarded as the manifestation of one god, whom those very Vedic Indians called the Supreme Brahman or Ultimate Reality. ${ }^{2}$ In the Rgveda, this Supreme Reality is expressed as ekam sad or 'That Real'. ${ }^{3}$ This concept originates the thinking of non-dual Reality which is developed and expressed to gain the idea of the Ultimate Reality. In the Upanisadic literature, the word 'Brahman' is used for the word Supreme Reality. The word Brahman is derived from the root brmh 'to grow'. In the Svetasvataropanisad, regarding the word Brahman Sankaracarya states that - brmhati brmhayati tasmaducyate param brahmeti. ${ }^{4}$ Brahman is mentioned as the soul and vital force of the universe from this all created things are generated. According to the Upanisadic literature, Brahman is that - from which all beings originate and which hold the all created beings in him. Brahman is that to which the all goes finally and in which the all created beings enter. ${ }^{5}$ The Atman is also considered as Brahman. ${ }^{6}$

In the most of the major Upanisads, the term Rudra is hardly seen, but in some minor Upanisads Rudra has been found as a distinct deity.

In the Svetasvataropanisad, Rudra is portrayed as only one, there is no place for a second one. He is present in all human beings. He rules these worlds by his ruling powers. He is the protector of the world. After having created the entire world, he merges them at the end of the time. ${ }^{7} \mathrm{He}$ is depicted as the omniscient seer (Maharsi), the cause of source and origin of all the deities, the lord of all as well as also the creator of Hiranyagarbha. ${ }^{8}$ From the above statement it can be known that Rudra appears as creator, preserver and destroyer. Rudra is considered as Girisanta and Giritra and the devotees pray to him to make his arrow gracious to them and do not to destroy their near and dears by striking that arrow. R.G. Bhandarkar comments - "He is called Girisa or Giritra, 'lying on a mountain', probably because the thunderbolt that he hurls, springs from a cloud, which is often compared to a mountain and in which he was believed to dwell." A number of names, viz. Hara, Isa, Isana and he is the lord of immortality, Mahesvara, Nilakantha, Adideva, Mahesa, Visvakarman and Mahatma are ascribed to the Brahman who is Rudra. He is also said to be Nilasikhanda, Babhru, Babhrukarṇa and Virupakșa, Girisa, Tamra (tawny coloured), Aruña (red in colour) and Vilohita or one who is blazing red in colour.

In the Nilarudropanisad, Rudra is known by several names. He is addressed as Bhavabhama and Bhavamanyu and salutation is paid to his arms and his arrows. He is portrayed as Nilagriva, Sikhandin and as coming down from the heaven to the earth, Jalasabhesaja. In the Puranic literature, Nilagriva, Sikhandin, Girisa, Nilasikhanda, Sahasraksa, Babhru, Virupaksa all these are used as names for Siva. There is nothing superior to Rudra in this universe, nothing higher, smaller and greater than him. He is the possessor of face, head and neck of all, present in the cavity of heart of all beings. He is called Bhagavan, all pervading, omniscient and Siva or bountiful. He remains in all beings and is called the inner soul of beings, the master of deeds, the witness and Nirguna. He is the quality of all 
senses as well as free from all the organs of senses. He is regarded as the lord, ruler and the shelter of all. Here, in this Upanisad, Rudra is stated as the Supreme Brahman having sahasrasira or thousand heads, thousand eyes and thousand feet, he is the great Purusa, omnipresent, powerful and supreme lord, the possessor of all sense organs and he is free from all the organs of senses and the lord, ruler as well as the shelter of all beings. He is the lord of all gods as well as the lord of two-footed and four-footed beings. According to this Upanisad, he is said to be the highest lord of the lords, supreme deity of the deities, great ruler of the rulers, the lord of the world and the most adorable god of the universe, he is female, male, young boy and young girl. Another reference has been found in this Upanisad where the nature (Prakrti) is referred to as Maya or illusion and the Mahesvara or great god is Mayin or illusion maker. Here, the word mahesvara is used as an adjective. But in the later period, this very word is used as a name of lord Siva. At the end of the fourth chapter of this Upanisad, a prayer addressing to Rudra is chanted where the devotees invoke to attain shelter in him and pray to protect through his daksina face.

In the Brhadaranyakopanisad, it is stated that the potentiality of eleven organs is called Rudra and as such Rudras are eleven in number. There are eleven organs in a human body. When they (eleven organs) leave the mortal body, they make everyone or relatives cry. As they make the relatives cry, they are called Rudras. ${ }^{10}$ In the Prasnopanisad, prana is identified with Rudra and Indra. ${ }^{11}$ In the Chandogyopanisad also pranas are identified with Rudras. ${ }^{12}$ In this connection, Sankaracarya remarks that pranas are Rudras because they make everyone cry.

A mantra has been found in the Brhadaranyakopanisad, where it is stated that the seven gods, viz. Rudra, Parjanya, Aditya, Agni, Indra, Prthivi and Dyu reside in the eyes and watch over it. Through the red lines which are in the eyes Rudra is subservient to it. According to P.M. Rath, "Rudra is here described as being present in the scarlet lines in the eyes. This idea reminds one of Rudra's associations with redness. Rudra is depicted as a red god and a deity, who emerged from the wrath of the gods and himself a wrathful deity." ${ }^{13}$ R.N. Dandekar also says that Rudra is a 'red god'. ${ }^{14}$ Rudra and Isana along with other gods, viz. Varuna, Indra, Soma, Parjanya, Yama, Mrtyu are known as Ksatram. According to Sankaracarya, ksatram means ksatriyajatim. ${ }^{15}$ In this context, Swami Nikhilananda's view can be cited. Swami Nikhilananda remarks in his book entitled The Upanishads that "The Brahmin caste is the maker of the spiritual culture and Ksatriya caste is the protector of the culture." 16

According to the Mahanarayanopanisad, Rudra is the superior to all and supreme seer. The worshippers pray to him (Rudra) to unite them (worshippers) with the supreme knowledge. ${ }^{17}$

In the Maitrayanyupanisad, Rudra and his other names are mentioned along with other gods as referring to Atman thus - esa hi khalvatmesanah sambhurbhavo rudrah prajapatirvisvasrgdhiranyagarbhah satyam prano hamsah sasta visnurnarayano'kah savita dhata vidhata samradindra induriti. Paul Deussen translates this mantra thus- "Indeed, this Atman is Isana, Sambhu, Bhava, Rudra, Prajapati, Visvasrj, Hiranyagarbha, the truth, life, bird of passage (Hamsa), ruler, Visnu, Narayana, Arka, Savitr, the creator, the regulator, the overlord or sovereign Indra, Indu." 18 Here Rudra is used as an epithet of Atman. Again Brahman is stated as Brahma, Visnu, Rudra, Prajapati etc. Here, it is visualized that Atman, Brahman, Rudra, Prajapati, etc. are the identical.

A reference has been found in the Jabalyupanisad, where it is said that when Pasupati becomes influenced by ahankara, he turns into the living being or jiva. Pasupati is omniscient, lord of all and performer of five kinds of actions. ${ }^{19}$ According to P.M. Rath, these five kinds of actions are creation, sustenance, destruction, benediction and vanishing. A jiva is known as a pasu and Pasupati is known as the master of jiva (living beings). Pasupati is used 
for a name of Rudra-Siva which is already mentioned in the previous chapter. This Upanisad describes a vrata, a kind of penance which includes wearing of the holy ash on different parts of body. The absolute principal (Pasupati) can be known only through this vrata. The Vedic reader has been told this vrata as Sambhava vrata. ${ }^{20}$ This vrata is mentioned as the means for the emancipation of living beings. If a brahmacari or sanyasi holds the holy ash on his body, he is free from all kinds of evils either greater or smaller; he becomes fit to worship all gods and becomes one who has recited the all Rudra hymns.

In the Pancabrahmopaniad, the five-fold aspects of the Supreme Brahman are described. Lord Siva is depicted as the Parabrahman or Supreme Brahman who has five aspects, viz. Sadyojata, Aghora, Vamadeva, Tatpurusa, and Isana. This Brahman or Siva always resides in the heart and exists as witness to all beings. ${ }^{21}$ In the Puranic literature, Lord Siva is identified with the Pancabrahma. He is said to be of five forms. Here, it is said that Isana is the first form of Siva Paramesthin, Tatpurusa is the second physical form, Aghora is the third, Vamadeva is the forth and Sadyojata is the fifth.

The Athravasiropanisad proclaims that Rudra is the principal of all things and the highest goal. He is past, present and future. There is nothing in this world except him. He resides in the heart of all living organisms. He is Nitya and Anitya, visible and invisible, east, west, south, north, above and below. He is the quarters and sub-quarters. He is said to be eldest, noblest and best, masculine, feminine and neuter. He is the fire in all forms, viz. garhapatya, dakșina and ahavaniya. ${ }^{22}$ Rudra is the form of Brahma, Visnu, Skanda, Indra, Agni, Vayu, Surya and Soma, Yama, Mrtyu etc. The highest Brahman is only one and he is Rudra. He is also Isana and the one who is Isana is also Mahesvara. ${ }^{23}$ Lord Siva is called by this name, Isana and Mahesvara in the Puranas. He (Rudra) is called Param Brahma because he is the highest of the highest, the strong and strengthens by the strong. There is a derivation of the word Rudra in the Athravasiropanisad. As per the derivation he is called Rudra because his existence (ru-pam) is grasped immediately (dru-tam) by the seers not by the other devotees. Nothing is earlier and later than Rudra, nothing what had been or nothing what was going to be. He pervades the world with thousand feet and one head. ${ }^{24}$

In the Kaivalyopanisad, lord Siva is depicted as Paramatman or Supreme one. This Supreme one sits in a pleasant posture with a pure mind. He is pure and free from sorrow, unthinkable, unmanifest and infinite, benevolent, calm, of the form of emancipation, source of brahmayoni. ${ }^{25}$ Paramatma being deluded by maya does every action in the universe having taken resort to a body sa eva mayaparimohitatma sariramasthaya karoti sarvam ${ }^{26}$

\section{CONCLUSION}

From the above discussion, it can be concluded that Rudra-Siva occupied a superior position in the Upanisadic literature. The concept of Rudra-Siva developed from this period. He is regarded as Brahman, lord of all, source of origin of all deities, Bhagavan, great god etc. It also said that he manifests himself into three forms, i.e. Brahma, Visnu, Mahesvara. At the very end, it can be said that Rudra-Siva occupied a higher position in the upanisadic period.

\section{END NOTE}

1. ayamatma brahma | Brhadaranyakopanisad, 4.4.5

2. kateva deva yajnavalkyetyeka ityomiti hovaca $\mid$ Ibid., 3.9.1

3. ekam sad vipra bahudha vadantyagnim yamam matarisvanamahuh | Rgveda, 1.164.46

4. Sankara on Svetasvararopanisad, 1.1

5. yato va imani bhutani jayante | yena jatani jivanti | yatprayatnabhisamvisanti | tadvijijnasatva tadbrahmeti || Taittiriya Upanisad, 3.1 
6. ayamatma brahma | Mahanarayanopanisad, 2

7. eko hi rudra na dvitiyaya tasthurya imanllokanisata isanibhih | pratyanjanastisthati samcukopantakale samsrjya visva bhuvanani gopah || Svetasvararopanisad, 3.2

8. Ibid., 3.4

9. Bhandarkar, R.G., Vaisnavism, Saivism and Minor Religious Systems, p.146

10. Brhadaranyakopanisad, 3.9.4

11. Prasnopanisad, 2.9

12. Chandogyopanisad, 3.16 .3

13. Vide, Rath, P.M., Rudra-Siva in the Vedas, pp.74-75

14. Dandekar, R.N., Vedic Mythological Tracts, p.256

15. Sankaracarya on Brhadaranyakopanisad, 1.4.11

16. Swami, Nilasikhanda, The Upanishads, Vol.III, p.126

17. Mahanarayanopanisad, 10.3

18. Vide, Deussen, P., Sixty Upanisads of the Veda, p.350

19. Jabalyupanisad, 11

20. ed. and revised by K.L. Joshi, O.N. Bimali and Bindiya Trivedi, 112 Upanișads, Vol. I, p.466

21. Pancabrahmopaniad, 40-41

22. Athravasiropanisad, 1

23. Ibid., 2-3

24. Ibid., 5-6

25. Kaivalyopanișad, 5-6

26. Ibid., 12

\section{REFERENCES}

[1] Bhandarkar, R.G. Vaisnavism, Saivism and Minor Religious Systems, New Delhi: Asian Educational Services, 1983.

[2] Dandekar, R.N. Vedic Mythological Tracts, Delhi: Ajanta Publication, 1979.

[3] Deussen, P. Sixty Upanișads of the Veda, Delhi: Motilal Banasidass, Vols. I \& II, 1987.

[4] Griffith, R.T.H. The Hymns of the Rgveda (English trans.), ed. by J.L. Shastri, Delhi: Motilal Banarsidass, 1986.

[5] Joshi, K.L and O.N. Bimali and Bindiya Trivedi, 112 Upaniṣads, Delhi: Parimal Publications, $3^{\text {rd }}$ edn., Vols. 1-2, 2007.

[6] Swami, Nikhilananda, The Upanishads, New York: Bonanza Books, Vol. I, 1949, Vol. II, 1952, Vol. III, 1956, Vol. IV, 1959.

[7] Rath, P.M. Rudra-Śiva in the Vedas, Delhi: Bharatiya Vidya Prakashan, 2011. 